\title{
Embedding Post-Capitalist Alternatives? The Global Network of Alternative Knowledge Production and Mobilization
}

\author{
William K. Carroll ${ }^{1}$ \\ University of Victoria \\ wcarroll@uvic.ca \\ J.P. Sapinski \\ University of Victoria
}

\begin{abstract}
Since the 1970s, transnational alternative policy groups (TAPGs) have emerged as a component of global civil society, generating visions and strategies for a "globalization from below" that point toward post-capitalist alternatives. Here, we map the global network of TAPGs and kindred international groups in order to discern how TAPGs are embedded in a larger formation. In this era of capitalist globalization, do TAPGs, like their hegemonic counterparts, bridge across geographic spaces (e.g. North-South) and movement domains to foster the convergence across difference that is taken as a criterial attribute of a counter-hegemonic historical bloc? Our network analysis suggests that TAPGs are well placed to participate in the transformation of the democratic globalization network from a gelatinous and unselfconscious state, into an historical bloc capable of collective action toward an alternative global order. However, there are gaps in the bloc, having to do with the representation and integration of regions and movement domains, and with the salience of post-capitalism as a unifying social vision. Also, our architectonic network analysis does not reveal what the various relations and mediations in which TAPGs are active agents actually mean in concrete practice. There is a need both for closer analysis of the specific kinds of relations that link transnational alternative policy groups to other international actors, including intergovernmental organizations and funding foundations, and for field work that explores the actual practices of these groups, in situ.
\end{abstract}

Keywords: Transnational networks, counter-hegemonic bloc, North-South ties, social movements

The production of knowledge that can inform practices to create alternative economic and political futures is a crucial task for scholars and activists today (Gibson-Graham 2006; Wright 2010). Given capitalism's global reach, alternative think tanks that bring to these production processes a transnational viewpoint and that mobilize knowledge for transnational publics are of particular strategic import. Since the 1970s, transnational alternative policy groups (TAPGs)

\footnotetext{
${ }^{1}$ This research was supported by the Social Sciences and Humanities Research Council of Canada.
} 
have emerged as a component of global civil society (GCS), generating visions and strategies for a "globalization from below" that points toward post-capitalist alternatives. Such groups as the Transnational Institute (Amsterdam), Focus on the Global South (Bangkok), the International Forum on Globalization (San Francisco) and the Centre for Civil Society (Durban) have served as "collective intellectuals" in facilitating the construction of a fledging historical bloc that transects national borders and poses democratic alternatives to neoliberal globalization (Carroll 2011).

This study explores a social network of alternative think tanks that critique capitalist economic and social organization and that might be said in some respects to foster practices of transition from a capitalist present to a post-capitalist future. We proceed from a neo-Gramscian understanding that hegemonic think tanks and TAPGs are embedded in opposing historical blocs, as they develop and deploy knowledge with the intent to make their respective blocs more coherent and effective (Carroll 2007). The hegemonic bloc can be conceptualized as a variegated, multi-tiered network of institutions, organizations, publics and individuals that provide leadership in the ongoing globalization of capitalism (cf. Smith 2008). Such globalization "from above" can incorporate reformist initiatives that address concerns expressed "from below" - as in the World Bank's opening to civil society in the late 1990s, or more recent advocacy of the "green economy," but cannot subvert "the decisive function exercised by the leading group in the decisive nucleus of economic activity" (Gramsci 1971: 161).

Earlier research focusing on the world's largest corporations and the key transnational policy groups whose boards interlock with them established that the policy boards are not only purveyors of the neoliberal ideas that govern global capitalism, but that they serve as important meeting places for key members of the transnational capitalist class (Carroll and Carson 2003; Carroll and Sapinski 2010). Groups like the World Economic Forum, the Trilateral Commission and the World Business Council for Sustainable Development pull together business leaders from mainly Europe and North America into shared social spaces where common strategic approaches to policy can be hammered out (Carroll and Carson 2003). A longitudinal network analysis of the decade ending in early 2007 pointed to "a process of structural consolidation through which policy boards have become more integrative nodes in the global corporate power structure," creating a denser transnational corporate-policy network with more extensive reach (Carroll and Sapinski 2010: 530) - structurally speaking, a transnational historical bloc dominated by North-Atlantic capital.

The issue we explore in this paper extends from a recent study of a comparable sample of 16 TAPGs and the international organizations with which they are connected, which found evidence of "a nascent historical bloc in which transnational alternative policy groups figure importantly, a network of counterpublics organically articulated to a range of movements opposing neoliberal globalization (if not capitalism)" (Carroll 2011: 18). Here, we map the global network of TAPGs and kindred international groups - alternative media, social movement organizations, and international NGOs - in order to discern more specifically how TAPGs are embedded in a larger formation. In this era of capitalist globalization, are TAPGs, like their hegemonic counterparts, positioned as "brokers," bridging across geographic spaces (e.g., NorthSouth) and movement domains to foster the "convergence across difference" (Conway 2004) that is taken as a criterial attribute of a counter-hegemonic historical bloc? Alternatively, are there ways in which the global network is factionalized, as in the fissure between ecological and social justice politics that characterized activist networks in the 1990s? In short, what can a network analysis tell us about how transnational alternative policy groups may be structurally embedded 
to facilitate the development of post-capitalist politics, which implies movement beyond the fragments of single-issue politics encased within nation states?

We explore two possible sources of cleavage in the global network: regional divisions the legacy of imperialism that is encoded in global North and global South - and discursive divisions - differences in how internationally-oriented groups frame their political projects. Clearly, prospects for effective post-capitalist politics hinge significantly on building bridges between activism in North and South as well as on the capacity of movements to converge upon framings of the political context "that highlight the degree to which a system is open to change" (Smith and Wiest 2012: 38).

\section{Counter-Hegemony and Global Civil Society: Embedding Post-Capitalist Alternatives}

Global civil society has been defined as "the realm of non-coercive collective action around shared interests and values that operates beyond the boundaries of nation states" (Glasius, Kaldor, and Anheier 2006: v). Often idealized as a coherent collection of world citizens pursuing social justice, global civil society can be more productively conceptualized as a field of conflict and struggle, distinct from the global economy and the inter-state system yet internally related to both. While helping to reproduce global hegemony, global civil society offers a "discursive space" and a foothold to counter-hegemonic politics (Ford 2003: 129).

This terrain has long been dominated by a cosmopolitan bourgeoisie, reflecting the superior material and cultural resources of a dominant class (van der Pijl 1998). In the twentieth century a network of business-oriented think tanks and policy groups entered the field, including the Mont Pèlerin Society and Trilateral Commission - important sites of hegemonic knowledge production and mobilization (KPM), sometimes known as "policy-planning" (Domhoff 2006). By the century's closing decades a new breed of "advocacy think tanks" (Abelson 1995) were actively shaping the neoliberal project of market-centered life (Stone 2000; Burris 2008; Macartney 2008). However, the brutalizing impact of neoliberal policies provoked a variegated grassroots politics of "alter-globalization" - resisting the "corporate agenda" but also putting forward democratic alternatives (Smith 2008; Stephen 2009; Coburn 2010).

Among the challenges faced by alter-globalization movements is that of counterhegemonic KPM - the production and promulgation of alternative strategies and visions that, as taken up in practice, might foster a cathartic shift from the episodic, fragmented resistances typical of subalternity to a shared ethico-political project that can become "a source of new initiatives" (Gramsci 1971: 367). The groups investigated in this research aspire to such counterhegemonic KPM. Our focus here is on specifically transnational alternative policy groups that pose their politics globally. They have sought to provide intellectual leadership for transnational movements and have come to occupy a unique niche within the organizational ecology of global justice politics.

The concept of embeddedness offers a rich metaphor for this analysis, based primarily in two strands of literature that originate from contributions by Karl Polanyi and Mark Granovetter. For Polanyi (1944), the great transformation that brought modern capitalism also brought a disembedding of markets from communities, and a "second movement" that endeavored to reembed - with the latter appearing in several distinct genres, including socialism and fascism. Granovetter's (1985) less sweeping concept of embeddedness focused on the problem of 
atomism in liberal economics, insisting on "the intrinsically relational nature of all social action" (Krippner and Alvarez 2007: 231).

Both senses of embeddedness are relevant to our study of TAPGs. As for the first, in producing and mobilizing alternative knowledge, TAPGs struggle against the market logic of capitalist disembedding; they offer cognitive resources to re-embed economic relations, under democratic control. Ideologically, Somers and Block (2005) point out that the hegemony of neoliberalism actually embeds the market within structures of common sense, particularly in the domain of political policy but also in wider cultural fields. TAPGs are to a considerable degree engaged in discursive struggles to dislodge neoliberalism from its embeddedness within common sense, but their intellectual production extends beyond critique to the advancement of alternative visions, strategies and policies. To have effect, however, this praxis must produce not simply knowledge of post-capitalist alternatives; it must produce - in collaboration with the agency of allied groups - transnational counter-publics, cultures of solidarity and communities of practice that instantiate that knowledge, embedding it in and beyond their own lifeworlds. This sort of embedding is not centered upon national states (as in Polanyi's formulation from the 1940s); the emphasis is on constructing critical knowledges and solidarities, across borders, within global civil society - understood as a terrain of contention (Conway and Singh 2009).

For the purposes of this paper, we work with Granovetter's network concept of embeddedness. Focusing on a purposive sample of 16 TAPGs - eight based in the global North and eight based in the global South - we ask how these sites of alternative knowledge production and mobilization are embedded in a larger network of international NGOs (INGOs), and what the nature of that positioning might mean for their capacity, as cultural and political agencies, to embed post-capitalist alternatives.

\section{Method}

Our analysis centers upon a judgment sample of 16 major TAPGs, each of which satisfies these criteria:

- a core function of knowledge production and mobilization that challenges existing political-economic hegemonies and presents alternatives, creates new paradigms, etc.;

- a significant part of that cognitive praxis takes up transnational issues and speaks to transnational counter-publics;

- the group engages a wide range of issues, i.e., it is not specialized in one domain (such as water, trade, or capital-labor relations).

The groups were selected to achieve geographical representation of every region of the world, with recognition of the fact that Europe contains a particularly large contingent of INGOs, relative to the rest of the world (Smith and Wiest 2012: 62). Table 1 offers a temporally sequenced list of the 16 TAPGs. Four groups formed in the mid-1970s (three of them based in the global North), at the culmination of the 1960s protest wave, and as the crisis of the post-war era set in. Four (all based in the global South) formed in the 1980s. In the past couple of decades, and particularly from the mid-1990s to 2005, TAPGs proliferated as an intellectual aspect of the gathering global democracy movement, but also as critical responses to the crises and contradictions of neoliberal globalization (Carroll 2013). 
Table 1. Judgment sample of 16 TAPGs

\begin{tabular}{clll}
\hline Est'd & \multicolumn{1}{c}{ Name } & \multicolumn{1}{c}{ Headquarters } & \multicolumn{1}{c}{$\begin{array}{c}\text { On WSF } \\
\text { Intl. Council }\end{array}$} \\
\hline 1974 & Transnational Institute (TNI) & Amsterdam & Yes \\
1975 & Third World Forum (TWF) & Dakar, Senegal & Louvain-la-Neuve (BE) \\
1976 & Tricontinental Centre (CETRI) & Yes \\
1976 & Centre de recherche et d'information pour le developpement & Paris & Yes \\
1982 & SCRID) & New Delhi & Penang \\
1984 & Third World Network (TWN) & Manila & Yes \\
1984 & Development Alternatives with Women for a New Era (DAWN) & Montevideo & Yes \\
1989 & Third World Institute/Social Watch (ITeM) & Berlin & Yes \\
1990 & Rosa Luxemburg Foundation (RosaLux) & San Francisco & Yes \\
1994 & International Forum on Globalization (IFG) & Bangkok & Yes \\
1995 & Focus on the Global South (Focus) & Helsinki & Yes \\
1997 & Network Institute for Global Democratization (NIGD) & Tokyo & Durban \\
1998 & People's Plan Study Group (PPSG) & Montreal & New Delhi \\
2001 & Centre for Civil Society (CCS) & Alternatives International (Alter-Inter) & \\
2005 & India Institute for Critical Action: Centre in Movement (CACIM) & New & \\
\hline
\end{tabular}

${ }^{a}$ Participates in World Social Forum International Council through World Forum for Alternatives, a joint venture with CETRI.

These 16 groups are diverse in organizational form and political priorities, including the extent to which they focus their efforts on prefigurative KPM that is relevant to the construction of alternative futures, as distinct from the critique of existing reality (cf. Coy et al. 2008). Groups such as the Third World Network (TWN), the Tricontinental Centre (CETRI) and Third World Institute/Social Watch (ITeM) focus on critique of current political-economic conditions; CACIM and the Network Institute for Global Democratization (NIGD) emphasize the construction of "open spaces" for political dialogue; groups like Focus on the Global South (Focus), the International Forum on Globalization (IFG) and the Transnational Institute (TNI) consciously strive to construct counter-hegemonic projects that prefigure actual alternatives to neoliberal capitalism, as in Focus' "deglobalization" paradigm, IFG's post-capitalism project and TNI's New Politics initiative. Despite these specificities (explored in more detail in Carroll 2013), the political sensibilities of all 16 groups seem to converge upon a conception of sustainable human development that blends radical-democratic and ecological imaginaries.

\section{Data Collection}

Our main source of information, for TAPGs and other organizations, was the Yearbook of International Organizations (YIO, online edition, 2012). Following a snowball sampling methodology, we used the $Y I O$ to collect the list of all first- and second-order neighbors of the initial 16 TAPGs, as presented in Table 2. First-order neighbors are organizations directly linked to one or more TAPG, and thus in the immediate neighborhood of TAPGs. Second-order neighbors are in the immediate neighborhoods of one or more first-order neighbors, but not directly linked to a TAPG.

The $Y I O$ lists a variety of types of relationships between organizations: resource and financial flows (as when an organization supports another by providing funding, office space, or 
other types of support); information flows (as when an organization acts as a consultant or advisor for another, or is an accredited observer at meetings); partnerships and collaborations taking the form of short term joint projects or long term alliances; coordination of an organization by another one (e.g., representation on the board or coordinating committee); and the various flows and collaborations taking place between organizations and their membership. For the purposes of this study, we assumed that all these links were indicative of a substantial relationship between organizations, and thus included them all in the analyses presented in the latter sections of this paper (see Katz 2006 for a similar use of YIO data). We gathered data on all relationships connecting TAPGs directly to their first- and indirectly to their second-order neighbors, plus all relations among the first-order neighbors. In effect, we used a 1-network sampling strategy to take a core network (the 16 TAPGs) and then to include all nodes linked to the nodes within the core network (Wasserman and Faust 1994), but we supplemented this with relations between the 1-network and all international organizations linked to any of its members. To keep the focus on civil society organizations, international governmental organizations, states and state agencies were excluded, yielding a sample of INGOs, broadly construed. ${ }^{2}$

Although the $Y I O$ provides extensive listings of INGOs, its coverage is not complete. In the case of TAPGs that did not have an entry in the $Y I O$, we gathered data on links we judged to be equivalent to $Y I O$ relationships, from the organizations' websites. For three TAPGs, information was not available from either the $Y I O$ or the organizations' websites. They were contacted by email, and two graciously provided a list of the organizations they collaborate or otherwise have substantial relationships with, which we included in our database. The other did not reply to our request and was thus excluded from the study. For first-order neighbors, we limited our data collection to the $Y I O$, or to organizations' websites in the case they were absent from the $Y I O{ }^{3}$

As Table 2 and Figure 1 show, TAPGs are indeed embedded in an extensive network. Their intersecting neighborhoods add 247 INGOs to the network. Taking the neighborhood to include second-order neighbors adds another 3714 INGOs. The sociogram shows the configuration as a cloud with TAPGs at or near the center, a result to some degree built into our snowball method. ${ }^{4}$

\footnotetext{
${ }^{2}$ For simplicity's sake, we will refer to organizations in our sample as INGOs, in that they are all non-governmental and non-corporate. As mentioned earlier, the sample includes TAPGs and their various network neighbors - the latter comprising a diverse array of international organizations, some of which are social movement organizations with mass memberships. For discussion, see Smith and Wiest (2012).

${ }^{3}$ The $Y I O$ provides access to a vast amount of data that are presented in a standardized format and are relatively upto-date. The data are based on questionnaires filled out by each organization listed, and the information is checked against other sources by $Y I O$ editors. The editors recognize that the information may nonetheless be incomplete and inconsistent at times, depending on the resources each organization is able to devote to responding to the questionnaire and the degree of motivation they have to do so (YIO 2012). Despite these minor shortcomings, we believe the $Y I O$ is in general very reliable for the purposes of this research. There is no known systematic bias in the data, and the only issue that may arise is that some links would be underreported by the $Y I O$, thus leading to more conservative estimates about the degree of connectivity of the whole network of INGOs.

${ }^{4}$ For TAPGs and their first-order neighbors we include all links to other INGOs but for second-order neighbors we include only links to first-order neighbors of TAPGs. This has the effect of consigning second-order neighbors to the network's periphery.
} 
Table 2. Sample structure

\begin{tabular}{lcc}
\hline \multicolumn{1}{c}{ Sample section } & n & \% \\
\hline Transnational alternative policy groups (TAPGs) & 16 & 0.4 \\
First-order neighbors & 247 & 6.2 \\
Second-order neighbors & 3714 & 93.4 \\
Total & 3977 & 100.0 \\
\hline
\end{tabular}

In addition to network data, we browsed each organization's website to gather individuallevel data for all TAPGs and their first-order neighbors. We first geocoded the location of each organization according to the city in which its headquarters are located. Second, we classified each according to a typology of its main activity, such as alternative media, social movement, NGO, foundation, and so on. Finally, we also collected information about the main "movement domain" of each organization, i.e. the way each frames its action in relation to what it sees as the main problem to be addressed: for example, ecology, globalization, capitalism, or patriarchy (see the analysis section for more detail on the coding). Tabulations were produced using UCInet 6 (Borgatti et al. 2002); graphs were produced using ORA, version 2.3.6 (Carley et al. 2012).

\section{Figure 1. The first-order and second-order neighborhoods of TAPGs}

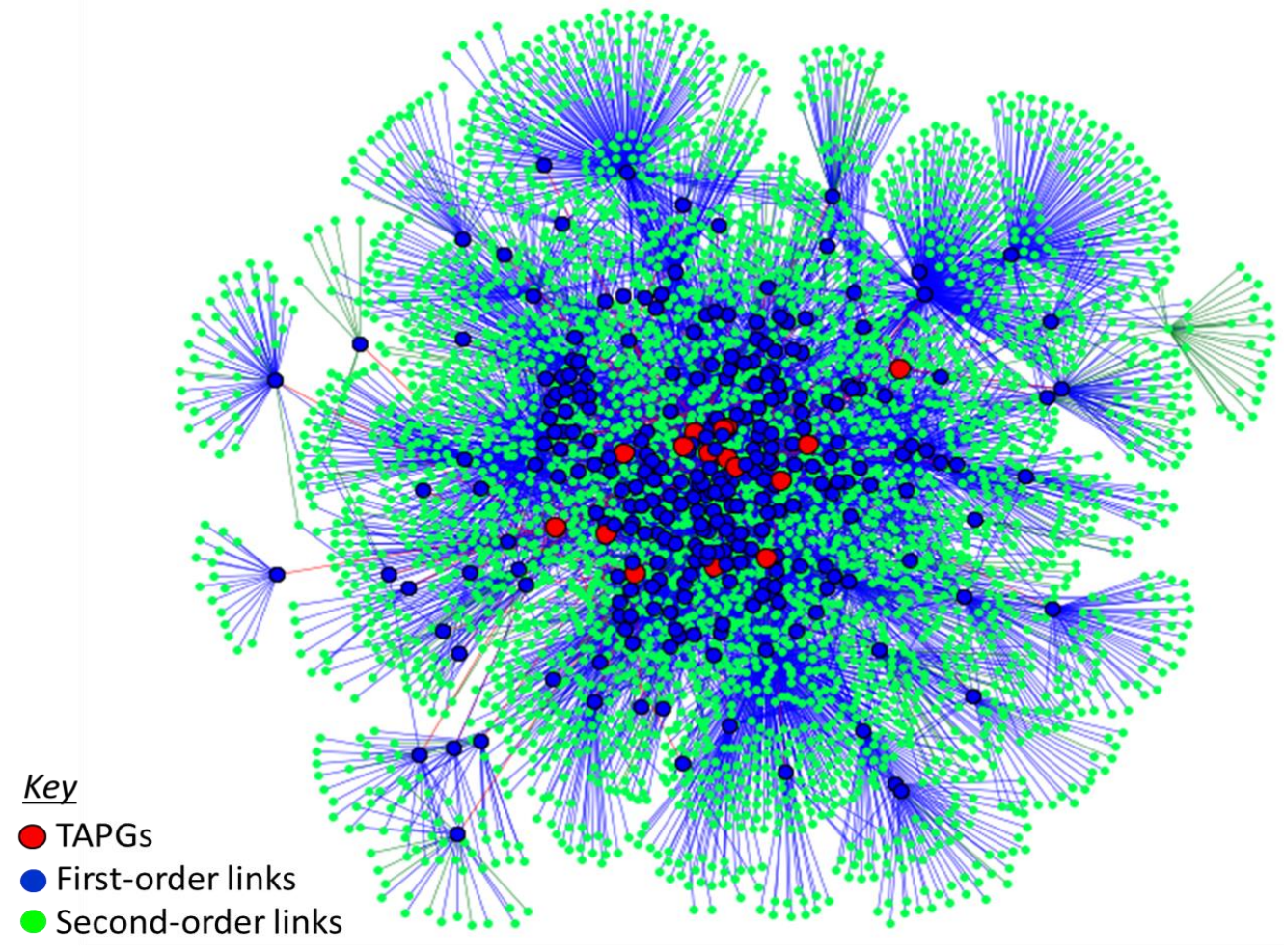




\section{Findings}

\section{TAPGs within Civil Society: Basic Patterns and Parameters}

The issue of embeddedness is multifaceted. Our first approach takes the perspective of network centrality. On this issue, our snowball method of case selection allows us to compare the centrality of TAPGs with the 247 INGOs in their immediate neighborhoods, which include many well-known organizations. Table 3 lists the organizations in the sample with the highest degree centrality, calculated on the basis of ties involving all 3977 organizations, and shows the centrality ranking of each TAPG within the network. Degree centrality is the sum of all incoming and outgoing ties of an organization (see Freeman 1978/1979). Given the structure of the data (which excludes relations among second-order neighbors to TAPGs), degree is the only measure of centrality that can be meaningfully computed for the network of TAPGs and their 247 immediate neighbors. This affords us a comparison of the relative centrality of transnational alternative policy groups among the 263 INGOs.

Here, we find the bulk of TAPGs to inhabit spaces near but not at the network center. Two TAPGs - Focus on the Global South and CRID - appear among the top 30, and nine others rank among the top 100 organizations of the 263 for which we collected complete network data. However, five TAPGs, all of them based in the global North, occupy positions more on the margins of the network (though only two are notably marginal). Overall, TAPGs show a slightly higher mean degree than the INGOs in their immediate neighborhoods, with respective means of 36.75 and $29.91\left(n=263\right.$; eta $\left.^{2}=0.0013\right)$. When we consider the geographical location of their headquarters, we find that TAPGs based in the global South are particularly well connected within the network, which stands to reason since the five relatively marginal TAPGs are all Northern-based. The mean degree for Southern-based TAPGs, 45.13, is considerably higher than the mean for TAPGs from the North $(28.38),\left(n=16\right.$; eta $\left.^{2}=0.1575\right)$.

Table 3. 30 most central organizations in the network of 3977 INGOs

\begin{tabular}{llcll}
\hline Rank & \multicolumn{1}{c}{ Name } & Degree centrality & \multicolumn{1}{c}{ City } & Country \\
\hline 1 & EarthAction Network (EAN) & 376 & Amherst (MA) & United States \\
2 & Khanya College & 287 & Johannesburg & South Africa \\
3 & Climate Justice Now! (CJN) & 278 & No single location ${ }^{b}$ & Philippines \\
4 & NGO forum on the Asian Dev. Bank (NGOADB) & 215 & Quezon City & Kenya \\
5 & ELC International (ELCI) & 180 & Nairobi & Brazil \\
6 & IBASE & 175 & Rio de Janeiro & South Africa \\
7 & Civicus & 145 & Johannesburg & Canada \\
8 & Alternatives & 136 & Montreal & Brazil \\
9 & World Social Forum (WSF) & 127 & Saõ Paulo & United States \\
10 & InterAction & 123 & Washington (DC) & Belgium \\
11 & ITUC & 120 & Brussels & South Africa \\
12 & Global Campaign Against Poverty (GCAP) & 119 & Johannesburg & United States \\
13 & Global Justice Ecology Project (GJEP) & 114 & Hinesburg (VT) & The Netherlands
\end{tabular}


Table 3. 30 most central organizations in the network of 3977 INGOs

\begin{tabular}{|c|c|c|c|c|}
\hline Rank & Name & Degree centrality & City & Country \\
\hline 15 & ENDA & 104 & Dakar & Senegal \\
\hline 16 & AWID & 102 & Toronto & Canada \\
\hline 17 & Development and Peace (CCODP) & 100 & Montréal & Canada \\
\hline 18 & ActionAid & 95 & Johannesburg & South Africa \\
\hline 19 & Ubuntu & 86 & Barcelona & Spain \\
\hline 20 & Carbon Trade Watch (CTW) & 85 & Barcelona & Spain \\
\hline 21 & Coordination SUD (CSUD) & 84 & Paris & France \\
\hline 22 & Focus on the Global South ${ }^{\mathrm{a}}$ & 83 & Bangkok & Thailand \\
\hline 22 & IRED & 83 & Geneva & Switzerland \\
\hline 24 & CLACSO & 82 & Buenos Aires & Argentina \\
\hline 25 & CODESRIA & 81 & Dakar & Senegal \\
\hline 26 & Society for International Development (SID) & 81 & Rome & Italy \\
\hline 27 & $\mathrm{CRID}^{\mathrm{a}}$ & 79 & Paris & France \\
\hline 28 & ACODEV & 76 & Brussels & Belgium \\
\hline 29 & Terrazul Alternative Association & 75 & Fortaleza & Brazil \\
\hline 30 & Globalization Studies Network (GSN) & 74 & Washington (DC) & United States \\
\hline 44 & Centre for Civil Society $(\mathrm{CCS})^{\mathrm{a}}$ & 53 & Durban & South Africa \\
\hline 54 & Third World Forum (TWF) ${ }^{\mathrm{a}}$ & 43 & Dakar & Senegal \\
\hline 55 & DAWN $^{\mathrm{a}}$ & 41 & Quezon City & Philippines \\
\hline 55 & ITeM / Social Watch ${ }^{\mathrm{a}}$ & 41 & Montevideo & Uruguay \\
\hline 57 & Rosa Luxemburg Foundation ${ }^{a}$ & 40 & Berlin & Germany \\
\hline 60 & Third World Network (TWN) ${ }^{\mathrm{a}}$ & 39 & Penang & Malaysia \\
\hline 60 & Transnational Institute (TNI) ${ }^{\mathrm{a}}$ & 39 & Amsterdam & The Netherlands \\
\hline 65 & PRIA $^{\mathrm{a}}$ & 36 & New Delhi & India \\
\hline 91 & CACIM $^{\mathrm{a}}$ & 25 & New Delhi & India \\
\hline 131 & People's Plan Study Group ${ }^{a}$ & 18 & Tokyo & Japan \\
\hline 146 & Alternatives International (Alter-Inter) ${ }^{\mathrm{a}}$ & 16 & Montréal & Canada \\
\hline 146 & International Forum on Globalization (IFG) ${ }^{a}$ & 16 & San Francisco & United States \\
\hline 182 & CETRI $^{\mathrm{a}}$ & 11 & Louvain-la-Neuve & Belgium \\
\hline 214 & $\mathrm{NIGD}^{\mathrm{a}}$ & 8 & Helsinki & Finland \\
\hline
\end{tabular}

${ }^{\mathrm{a}}$ Transnational alternative policy group (TAPG).

${ }^{b}$ This organization does not have a headquarter in a fixed location.

When we map the relations between the 44 organizations in Table 3, we arrive at the configuration in Figure 2. This sociogram uses a spring embedded algorithm that projects the nodes in a two-dimensional space so that those with the shortest path lengths also appear the closest in the graph (Hanneman and Riddle 2005). The points representing TAPGs are circled by rings. Even though few of them appear among the 30 most central nodes, TAPGs nonetheless link tightly to the central organizations, with some of them (Focus, Third World Network, 
DAWN, RosaLux) acting as hubs that pull the network core closer together. Organizations from the global South (in gold) and the global North (in blue) seem to be fairly evenly distributed in the network, with TAPGs headquartered in the South occupying slightly more central positions. ${ }^{5}$

The position of the World Social Forum (WSF), ranked $9^{\text {th }}$ overall in degree centrality, at the center of this subnetwork, is striking. Contributing to its location are ties radiating to 12 TAPGs. Clearly the WSF, as an "open space" for considering the possibility of another world, has been a key site for the efforts of TAPGs. Indeed, TAPGs that are relatively marginal in the network overall, such as NIGD, IFG and CETRI, appear in this sociogram as fairly ensconced among core organizations, in part by virtue of their links to the WSF.

It is not surprising to find TAPGs near but not exactly at the core of the network. The most central positions are occupied by some of the major, well-resourced, international development NGOs and environmental networks with substantial membership bases, and by global forums that bring movements together on a cross-sectoral basis (WSF, Civicus, NGO Forum on ADB). As producers of alternative knowledge, TAPGs connect extensively with what Smith and Wiest (2012) call transnational social movement organizations, but they do not dominate the segment of global civil society in which they are immediately embedded. Rather, as they work interdependently with groups that are more oriented toward movement process (WSF) or political action (EAN, CJN, GCAP, FoEI), they connect with some of which are the most central in the network.

Figure 2. TAPGs among the 30 most central organizations, by region

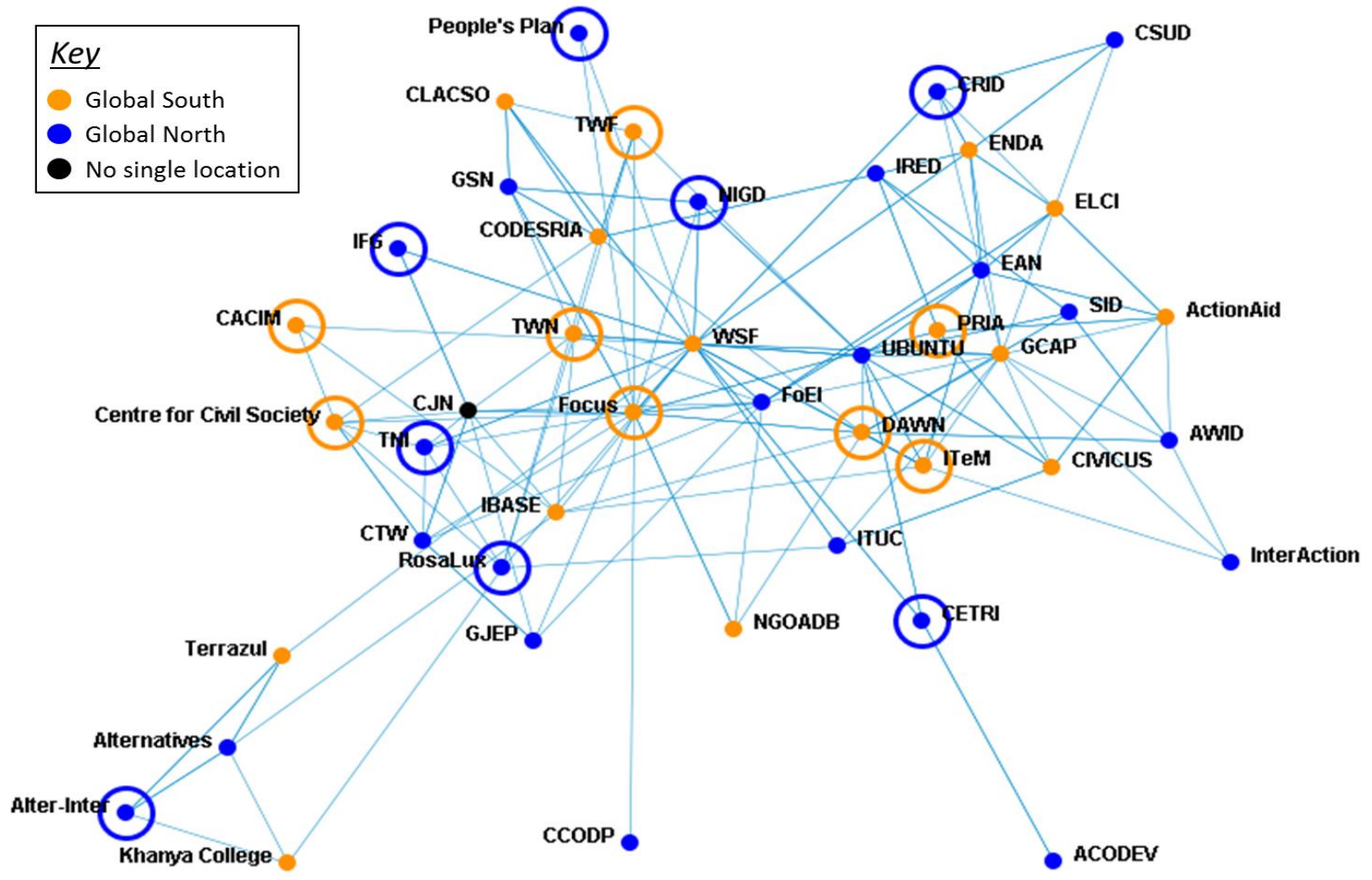

\footnotetext{
${ }^{5}$ As a cautionary note, although all of the INGOs in Table 3 except Climate Justice Now! have headquarters in specific cities, some, like DAWN, Alternatives International, and the World Social Forum, are global networks, whose headquarters simply house a secretariat. For these groups especially, the geocoded coordinates do not necessarily represent the center for actual activities.
} 
Embeddedness always has a spatial dimension. To explore this, in Figure 3 we map the entire network of 16 TAPGs and their 247 direct neighbors, according to the location of each organization's headquarters. One can observe extensive traffic across the North Atlantic, and in this respect the network bears some resemblance to the elite network associated with the transnational capitalist class (Carroll 2010). Similarly, organizations based in Europe are particularly prominent. However, Tokyo, a global city for business, is marginal to the network, while Southern cities like Durban, Montevideo and Manila appear as important switch points. Although many ties connect across North and South, there is also extensive networking among Southern-based INGOs, spanning South America, Africa and Asia. Conspicuously absent are organizations based in Russia and China. ${ }^{6}$

Figure 3. TAPGs and their immediate neighbors as a global network

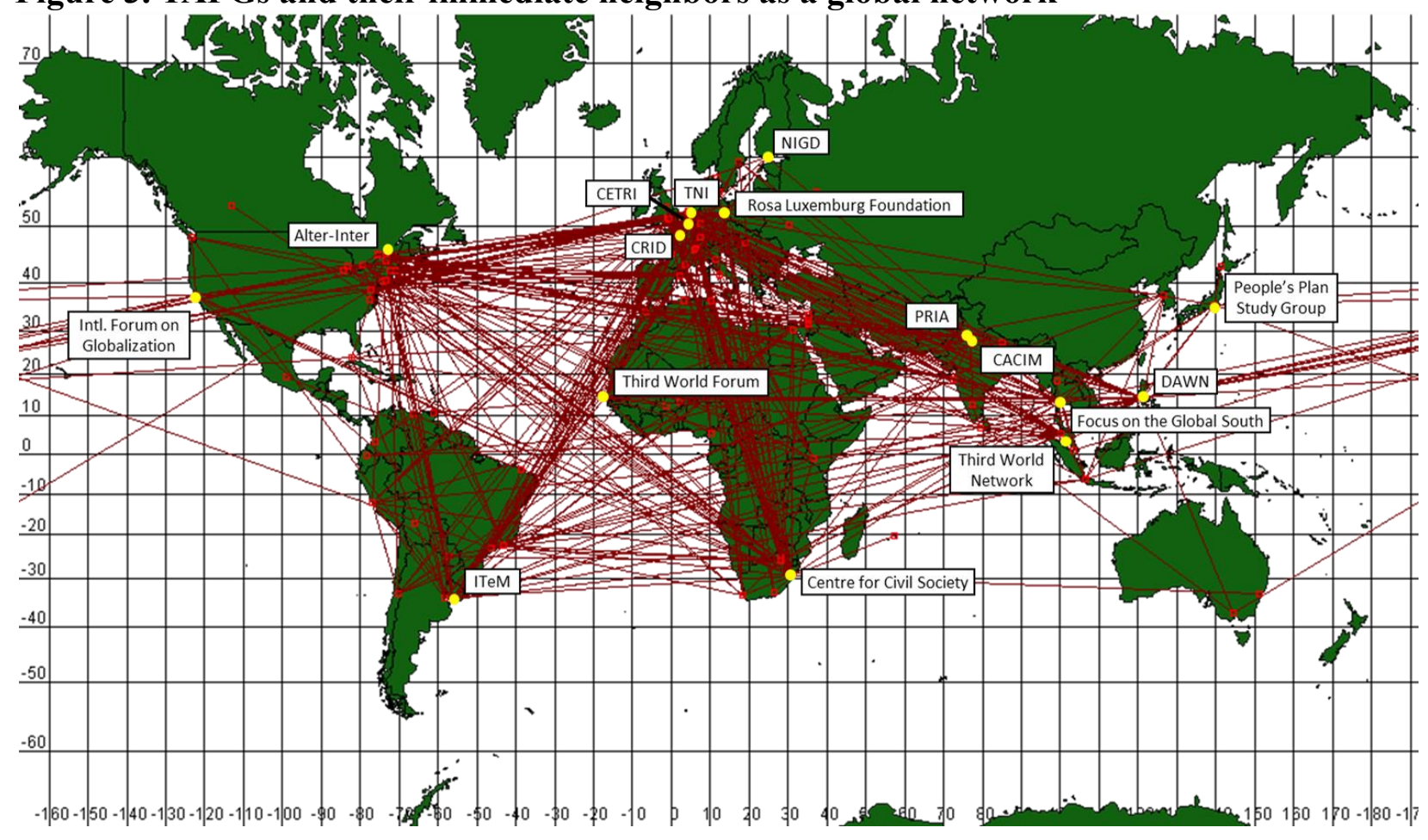

Embeddedness can also be appraised as an aspect of geodesic distance. Points can be connected directly, but in large networks most are mutually reachable only indirectly, through paths along which other points serve as intermediaries. The shortest path between a pair of points defines their geodesic distance. For the network of 16 TAPGs and their immediate neighbors, Table 4 provides the distribution of distances in the network.

Although only $2.3 \%$ of all organizations are directly connected, another $21 \%$ are linked at one remove, while $46 \%$ are reachable at two removes, i.e., nearly $70 \%$ of the 263 organizations can reach each other via no more than two intermediate network members. The network's diameter is 5 - for three percent of pairs of organizations a path across four intermediates is required. The mean distance in the network is 3.1 .

\footnotetext{
${ }^{6}$ These absences in part reflect initial sampling decisions, but they also reflect the fact that no INGO based in Russia or China had substantial ties to any of our 16 TAPGs.
} 
Table 4. Geodesic distances in the network of TAPGs and neighboring INGOs

\begin{tabular}{ccc}
\hline Distance & Frequency & \% \\
\hline 1 & 1,596 & 2.3 \\
2 & 14,354 & 20.8 \\
3 & 31,816 & 46.2 \\
4 & 19,084 & 27.7 \\
5 & 2,056 & 3.0 \\
\hline
\end{tabular}

Mean: $3.1 \quad$ Std. dev.: 0.8

These parameters give us a baseline for assessing the integrative contribution that TAPGs make to the segment of global civil society in which they are embedded. In a network organized around policy groups, a basic way of assessing the contribution policy groups make to structural cohesion is to assess the impact that removing the policy groups has on the connectivity of the other organizations. Carroll and Carson (2003) find that, for the transnational hegemonic bloc, removal of five key policy groups has a substantial structural effect, that the mediations of policy groups dramatically reduce distances between corporate boards in the interlock network. When we similarly dis-embed TAPGs from the transnational alternative policy network, the network also loses connectivity. Most obviously, 74 organizations disappear from the connected network (twelve of them form six dyads; the others become isolates). Among the 173 remaining organizations that form a single, connected component, mean distance increases from 2.092 when TAPGs are included as mediating agents, to 3.279 when we dis-embed them. In these comparisons we can see that the impact of TAPGs on the network is twofold: the fringes of their social circles bring 74 organizations into a connected configuration from which they are otherwise isolated; among the other 173 organizations the mediation of TAPGs in connecting across various global civil society groups reduces mean distance by $36.2 \%$. These findings show that TAPGs are embedded in a segment of global civil society which, although not without its own interconnections, derives considerable structural coherence and connectivity from the mediation provided by TAPGs.

\section{Inter-regional and North-South Mediation}

One of the main questions driving this paper is whether TAPGs bring the alter-globalization network closer together across space, especially between countries of the global North and those of the global South. Table 3 and Figure 3 already offer some indications as to the positions most TAPGs occupy near the center of the network. The analyses we present next explore the differences among TAPGs in their particular patterns of mediation.

Table 5 presents the regional distribution of TAPGs and directly linked organizations, using an eight-fold classification proposed by Smith (1997; also used by Shumate and Dewitt 2008 and Carroll 2010) that incorporates the core-periphery distinction within the world-system. As already emphasized in Figure 3, many organizations have their headquarters in Western Europe; North America, Asia, and Sub-Saharan Africa (especially South Africa) are also well represented. However, Eastern Europe and the Middle East/North Africa are under-represented in the network. 
Table 5. Regional distribution of TAPGs and neighboring INGOs

\begin{tabular}{lccl}
\multicolumn{1}{c}{ Region } & $\mathbf{n}$ & $\mathbf{\%}$ & \multicolumn{1}{c}{ TAPGs located in the region } \\
\hline Global North & & & \\
$\quad$ North America & 32 & 12.2 & Alter-Inter, IFG \\
Western Europe & 96 & 36.5 & CRID, CETRI, TNI, RosaLux, NIGD \\
Japan/Australia & 17 & 6.5 & People's Plan Study Group \\
Total - North & 145 & 55.1 & \\
\hline Global South & & & \\
Eastern Europe & 4 & 1.5 & \\
Middle East/North Africa & 13 & 4.9 & \\
Asia & 35 & 13.3 & CACIM, Focus, TWN, DAWN, PRIA \\
Sub-saharan Africa & 31 & 11.8 & CCS, TWF \\
Latin America/Carribean & 25 & 9.5 & ITeM / Social Watch \\
Total - South & 108 & 41.1 & \\
\hline Not based in a single region & 3 & 1.1 & \\
Missing & 7 & 2.7 & \\
\hline Total & 263 & 100.0 & \\
\hline
\end{tabular}

As embedded actors in global civil society, how do specific producers and mobilizers of alternative knowledge connect across spatial difference? At one extreme, that of complete introversion, an organization might maintain its entire network neighborhood within its own region; at the other, that of complete extraversion, its network neighborhood might be located entirely "elsewhere" - beyond its own spatial locale. We compared the extent to which TAPGs link within their own region and outside of it by calculating E-I (E minus I) indices. ${ }^{7}$ Positive numbers indicate extraversion (i.e. a predominance of ties that reach beyond the group's own region); negative numbers indicate the group links mostly within its own region. Table 6 shows two E-I indices for each TAPG, the first one calculated relative to the eight-fold categorization presented above (Table 5) and the second one based on a dichotomous North-South divide. In the latter case, a relation is introverted if it connects, say, a Northern TAPGs to another Northernbased organization, and extraverted if it connects, say, a Southern TAPG to an organization based in the North.

First, let us look only at the E-I index for the eight-region classification in Table 5. Overall, the 16 TAPGs are regionally extraverted: 198 of their 336 ties extend beyond a given group's region $(\mathrm{E}-\mathrm{I}=0.179)$. However, the patterns of extraversion-introversion vary quite substantially. All the Southern-based TAPGs are extraverted in their network relations, most of

\footnotetext{
${ }^{7}$ For present purposes, the E-I index represents, for each organization, the difference between the number of ties that reach out to another region (E) and the number of ties that stay within the organization's own region (I), divided by the total number of ties (E+I). For details on the E-I index see Krackhardt and Stern (1988).
} 
them extensively so. Northern-based TAPGs are much more variable along this dimension, and show a slight overall introversion. Among the northern introverts, CRID (E-I $=-0.784)$ participates at the heart of the French development NGO network while People's Plan Study Group in Japan (E-I $=-0.647)$ connects mostly with other Japan-based organizations. The "regionally introverted" TAPGs are all based in the global North. Among the most extraverted TAPGs, the ones with sizeable numbers of ties (Third World Network, DAWN, and PRIA) are all located in the South. Two TAPGs based in Europe (TNI and RosaLux), however, also show extensive ties beyond their region, as does Alternatives International, which is structured as an international network, with its secretariat based in Montreal. Combining the basic finding from Table 6 with our earlier analysis of degree centrality, we see that TAPGs located in the global South tend to engage in more extensive networking and to connect with organizations outside of their region, whereas Northern-based TAPGs network less, and some show an introverted tendency to link within their region.

Comparing the regional and North-South E-I indices provides us with more insight into the patterns of mediation by Northern- and Southern-based TAPGs. On the one hand, TAPGs in the North present almost the same patterns of extraversion-introversion, with a total North/South E-I of -0.323 , compared to -0.218 for the eight regions E-I. This indicates that their internal links tend to keep within their regions, whereas their external links connect them mainly to organizations located in the South. On the other hand, the E-I pattern varies much more markedly for TAPGs from the South, especially for the Third World Network, DAWN, and the Third World Forum. These groups are extraverted in their ties across the eight regions, but introverted when it comes to the North/South divide: their ties span across the regions of the global South, but connect less to organizations in the North. Overall, Southern-based TAPGs show a mild tendency to connect with other organizations of the South $(\mathrm{E}-\mathrm{I}=-0.143)$. Thus, their relatively pronounced extraversion across the eight regions $(E-I=0.438)$ signifies that they mainly bridge across regions of the global South. Only Focus and PRIA are extraverted toward the North while Centre for Civil Society and ITeM/Social Watch show a balance in their North/South ties.

Table 6. Extraversion - Introversion of individual TAPGS $(n=253)^{a}$

\begin{tabular}{|c|c|c|c|c|c|c|c|}
\hline \multirow[b]{2}{*}{ Organization } & \multirow{2}{*}{$\begin{array}{l}\text { Total } \\
\text { links }\end{array}$} & \multicolumn{3}{|c|}{ Region (8 categories) } & \multicolumn{3}{|c|}{ North // South } \\
\hline & & $\begin{array}{c}\text { Interna } \\
\mathbf{l}\end{array}$ & $\begin{array}{c}\text { Externa } \\
l\end{array}$ & $\mathbf{E}-\mathbf{I}$ & $\begin{array}{c}\text { Interna } \\
\mathbf{l}\end{array}$ & $\begin{array}{c}\text { Externa } \\
l\end{array}$ & $\mathbf{E}-\mathbf{I}$ \\
\hline
\end{tabular}

Global North

North America

Intl. Forum on

Globalization

Alternatives International

$7 \quad 5$

$2 \quad-0.429$

5

2

$-0.429$

Western Europe

CRID

10

1

$9 \quad 0.800$

2

$8 \quad 0.600$

CETRI

Transnational Institute

$\begin{array}{lr}4 & -0.784 \\ 2 & -0.200 \\ 9 & 0.125\end{array}$

33

$4 \quad-0.784$

53

16

7

0.125

3

$2 \quad-0.200$

9

7

$-0.125$ 
Table 6. Extraversion - Introversion of individual TAPGS $(\mathbf{n}=\mathbf{2 5 3})^{\mathrm{a}}$

\begin{tabular}{|c|c|c|c|c|c|c|c|}
\hline \multirow[b]{2}{*}{ Organization } & \multirow{2}{*}{$\begin{array}{l}\text { Total } \\
\text { links }\end{array}$} & \multicolumn{3}{|c|}{ Region (8 categories) } & \multicolumn{3}{|c|}{ North // South } \\
\hline & & $\begin{array}{c}\text { Interna } \\
1\end{array}$ & $\begin{array}{c}\text { Externa } \\
l\end{array}$ & $\mathbf{E}-\mathbf{I}$ & $\begin{array}{c}\text { Interna } \\
\mathbf{l}\end{array}$ & $\begin{array}{c}\text { Externa } \\
1\end{array}$ & $\mathbf{E}-\mathbf{I}$ \\
\hline $\begin{array}{l}\text { Rosa Luxemburg } \\
\text { Foundation }\end{array}$ & 36 & 17 & 19 & 0.056 & 19 & 17 & -0.056 \\
\hline NIGD & 5 & 1 & 4 & 0.600 & 2 & 3 & 0.200 \\
\hline \multicolumn{8}{|l|}{ Japan } \\
\hline $\begin{array}{l}\text { People's Plan Study } \\
\text { Group }\end{array}$ & 17 & 14 & 3 & -0.647 & 15 & 2 & -0.765 \\
\hline Total - North & 133 & 81 & 52 & -0.218 & 88 & 45 & -0.323 \\
\hline \multicolumn{8}{|l|}{ Global South } \\
\hline \multicolumn{8}{|l|}{ Asia } \\
\hline CACIM & 17 & 8 & 9 & 0.059 & 13 & 4 & -0.529 \\
\hline $\begin{array}{l}\text { Focus on the Global } \\
\text { South }\end{array}$ & 43 & 12 & 31 & 0.442 & 17 & 26 & 0.209 \\
\hline Third World Network & 22 & 5 & 17 & 0.545 & 13 & 9 & -0.182 \\
\hline DAWN & 22 & 5 & 17 & 0.545 & 15 & 7 & -0.364 \\
\hline PRIA & 16 & 3 & 13 & 0.625 & 6 & 10 & 0.250 \\
\hline \multicolumn{8}{|l|}{ Sub-saharan Africa } \\
\hline Centre for Civil Society & 39 & 12 & 27 & 0.385 & 20 & 19 & -0.026 \\
\hline Third World Forum & 23 & 7 & 16 & 0.391 & 21 & 2 & -0.826 \\
\hline \multicolumn{8}{|l|}{ South America } \\
\hline ITeM / Social Watch & 21 & 5 & 16 & 0.520 & 11 & 10 & -0.048 \\
\hline Total - South & 203 & 57 & 146 & 0.438 & 116 & 87 & -0.143 \\
\hline Total & 336 & 138 & 198 & 0.179 & 204 & 132 & -0.214 \\
\hline
\end{tabular}

${ }^{\mathrm{a}}$ Organizations that do not have a headquarters in a single location or for which no location could be determined (see Table 5) were excluded from this analysis.

Brokerage analysis provides another angle from which to consider how TAPGs mediate relations between the Northern and Southern segments of global civil society. An ego is said to broker between a pair of unconnected alters if it is linked to both of them, thus connecting them at one remove (see Gould and Fernandez 1989; Stovel and Shaw 2012). ${ }^{8}$ McAdam (2003) and

\footnotetext{
${ }^{8}$ As with any network analysis of brokerage, the criterion for the existence of a relationship influences the result. It is possible that some of the INGOs we identify as not directly linked together do have some contact with each other, but that the information was not recorded in the $Y I O$. However, there is no reason to assume that the overall pattern of results would change if such relations were included in the analysis.
} 
Vasi (2011) show that brokerage plays a major role in spreading contention more rapidly and across lines of fraction within civil society. As well, recent work by Von Bülow (2011) emphasizes how transnational civil society actors deliberately pursue brokerage strategies in seeking to build long-term collaborations between transnational civil society actors: thus the importance of looking at how TAPGs broker relations within the structure of global civil society.

We can parcel each TAPG's set of brokerages into those that mediate between two organizations of the global North (North-North), those that mediate between two organizations of the global South (South-South) and those that mediate between one organization of South and one of North (North-South). By definition, North-South brokerage helps integrate the Northern and Southern segments of global civil society. The significance of North-North and South-South brokerages for transnational historical bloc formation depends on the location of the mediating group itself. TAPGs based in the global North, whose brokerage relations mediate between other Northern-based groups, integrate the Northern region of global civil society. The same intraregional integration occurs when the brokering TAPG and the brokered relations are all contained in the South. Alternatively, however, Southern TAPGs that broker relations between Northern-based groups may be seen as engaging, from a Southern position, with the Northern region, thereby constructing bridges from South to North. Table 7 presents each TAPG's pattern of brokerage within and between the global South and the global North, using undirected absolute brokerage scores.

Table 7. Relations brokered by TAPGs between North and South $(n=253)^{a}$

\begin{tabular}{|c|c|c|c|c|}
\hline Organization & $\begin{array}{c}\text { Total } \\
\text { brokerage }\end{array}$ & $\begin{array}{l}\text { North- } \\
\text { North }\end{array}$ & $\begin{array}{l}\text { South- } \\
\text { South }\end{array}$ & $\begin{array}{l}\text { North- } \\
\text { South }\end{array}$ \\
\hline \multicolumn{5}{|l|}{ Global North } \\
\hline Rosa Luxemburg Foundation & 890 & 328 & 250 & 312 \\
\hline CRID & 823 & 764 & 2 & 57 \\
\hline People's Plan Study Group & 237 & 208 & 0 & 29 \\
\hline Transnational Institute & 117 & 38 & 36 & 43 \\
\hline Alternatives International & 46 & 0 & 40 & 6 \\
\hline Intl. Forum on Globalization & 14 & 10 & 0 & 4 \\
\hline CETRI & 11 & 4 & 2 & 5 \\
\hline NIGD & 10 & 2 & 4 & 4 \\
\hline Total - North & 2148 & 1354 & 334 & 460 \\
\hline \multicolumn{5}{|l|}{ Global South } \\
\hline Centre for Civil Society & 1075 & 330 & 380 & 365 \\
\hline Focus on the Global South & 695 & 354 & 116 & 225 \\
\hline Third World Network & 212 & 72 & 64 & 76 \\
\hline DAWN & 202 & 4 & 152 & 46 \\
\hline ITeM / Social Watch & 192 & 62 & 58 & 72 \\
\hline
\end{tabular}


Table 7. Relations brokered by TAPGs between North and South $(\mathrm{n}=\mathbf{2 5 3})^{\mathrm{a}}$

\begin{tabular}{lcccc}
\hline Organization & $\begin{array}{c}\text { Total } \\
\text { brokerage }\end{array}$ & $\begin{array}{c}\text { North- } \\
\text { North }\end{array}$ & $\begin{array}{c}\text { South- } \\
\text { South }\end{array}$ & $\begin{array}{c}\text { North- } \\
\text { South }\end{array}$ \\
\hline CACIM & 184 & 12 & 126 & 46 \\
PRIA & 71 & 38 & 10 & 23 \\
Third World Forum & 55 & 2 & 40 & 13 \\
Total - South & 2686 & 874 & 946 & 866 \\
\hline Total & 4834 & 2228 & 1280 & 1326 \\
\hline
\end{tabular}

${ }^{\mathrm{a}}$ Organizations that do not have a headquarter in a single location or for which no location could be determined (see Table 5) were excluded from this analysis.

We find a remarkable amount of variation among TAPGs in the overall volume of brokerage. Four groups - two in the South (CCS and Focus) and two in the North (RosaLux and CRID) - account for $72 \%$ of all the relations brokered by the 16 TAPGs. Among these four highvolume brokers, CRID mediates many Northern-based relations and extremely few Southernbased ones. It also links at one remove 57 Southern-based organizations with Northern-based ones, consistent with its project of building North-South solidarity relations around development issues. The other three show more even brokerage profiles, mediating within and across the two zones. TAPGs with few network connections are, of course, not heavily involved in brokerage, although the People's Plan Study Group mediates 208 North-North relations and 29 North-South ones. Alternatives International (which functions as an international network, with secretariat in Montreal) is the second most active South-South broker among the Northern-based TAPGs. Still in the North, the Transnational Institute and RosaLux display particularly balanced brokerage profiles, mediating between organizations based in and across the global North and South. Overall, TAPGs based in the North mostly broker relations between Northern INGOs, yet hundreds of these mediated relations involve pairs of Southern INGOs, or link South to North.

These latter, cross-regional brokerages are especially profuse among Southern TAPGs. Overall, the profile for Southern TAPGs is quite balanced. Whereas among the six Northern TAPGs $63 \%$ of brokerage is contained within the North, among the six Southern TAPGs 35\% of brokered relations are South-to-South, with the North-South and North-North categories claiming close to a third of all brokerage each. PRIA (whose project to proliferate knowledgedemocratizing practices in Asia and more globally links it to partners like UK-based Institute of Development Studies) is the only group for which a majority of mediations run North-North. DAWN, CACIM, and Third World Forum primarily broker between Southern-based INGOs, although DAWN and CACIM also participate in dozens of North-South mediations. The overall brokerage analysis shows Southern-based TAPGs to be involved in complex mediations that contribute to North-South solidarities as well as to the formation of a Southern network. As noted above, for Southern-based TAPGs, North-North brokerages are themselves instances of NorthSouth mediation. Thus, while most of the relations brokered by Northern TAPGs contribute to a Northern NGO network, the tendency for Southern-based TAPGs is to participate in (and mediate) that network while also building relations in the South and between Southern and Northern segments of global civil society.

To illustrate patterns of brokerage between North and South, Figure 4 presents sociograms of the immediate neighborhood of four TAPGs, two located in the global South and 
two in the global North. The patterns seem congruent with each group's specific project. In the North, CRID, a coalition whose purpose is in good part to build unity among progressive development NGOs, is embedded within a Western European network (in blue), which links to Coordination Sud and Ritimo, two major French NGO networks; hence, its brokerages run North-to-North. RosaLux, with a strong commitment to building a social base for democratic socialism in Germany and internationally, is well embedded within Western Europe, where it links with global trade union organizations such as the International Trade Union Confederation (ITUC), its European counterpart (ETUC), and the Trade Union Advisory Committee to the OECD (TUAC). But RosaLux, through its Center for International Dialogue and Cooperation, also has several neighbors in Sub-Saharan Africa (in yellow, including the Durban-based Centre for Civil Society) and in Latin America, Eastern Europe, and Asia. This combination of ties to Northern and Southern INGOs, which are not directly linked to each other, positions RosaLux as a broker within and across North and South.

In the South, consistently with the general observation that Southern-based TAPGs bridge between regions of the South, DAWN links extensively with organizations from Asia (in red), Sub-Saharan Africa (in yellow), and Latin America (in purple); it also collaborates with two North American development feminist NGOs: the Association for Women's Rights in Development (AWID) in Toronto and the Women's Environment and Development Organization (WEDO) in New York. DAWN's membership base (feminist scholar-activists based in the global South) and its explicit commitment to fostering a Southern feminism has led it to link across the global South, and thus to broker a good many South-South relations. Unlike DAWN, Focus, whose project is to "Focus on the Global South" in a way that strengthens North-South solidarity while building capacity in the South, links not only across the South but with all three regions of the North, thus bridging between, on the one hand, the Asian NGO network and, on the other hand, the networks of North America (in light blue), Western Europe, and Japan (in green). This pattern positions Focus as a North-South broker, but also means that it brokers across the regions of the North and, to a lesser extent, the South. 
Figure 4. Embeddedness of four key TAPGs within their respective neighborhoods

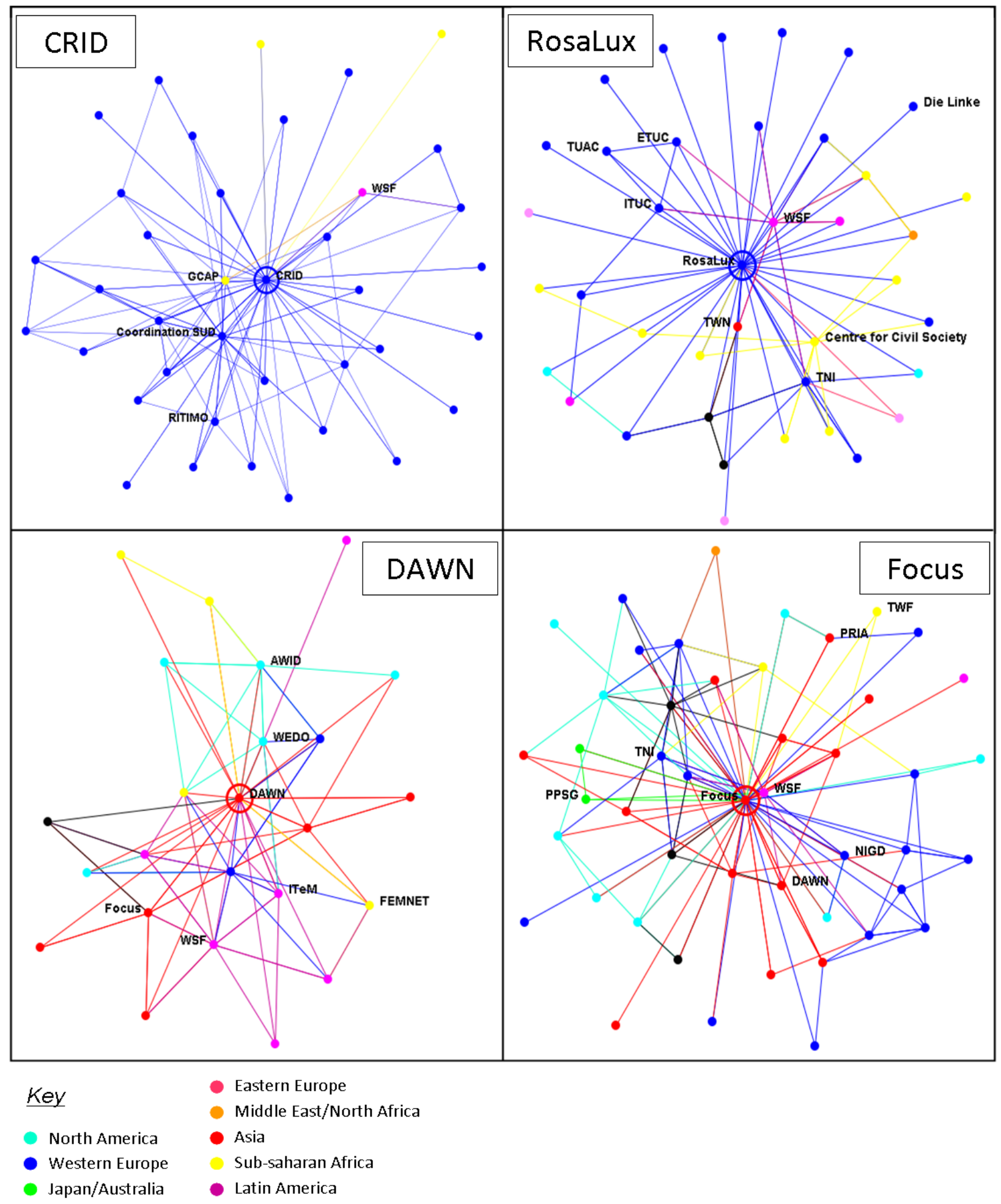




\section{Embeddedness and Mediation Among Movement Domains}

The formation of a global counter-hegemonic bloc requires reaching out across different regions of the world, but also across different locations within the conceptual space of alternative and oppositional politics. Movements distinguish themselves in part by frames they use in analyzing political issues and in constructing strategic pathways toward change (Snow and Benford 1992). To assess whether TAPGs do in fact bridge across this differentiated space, and the shape this mediation takes, we studied the websites of all TAPGs and their immediate neighbors and coded each organization into a domain category representing the predominant framing of its political project, including how each group defines the main problem it addresses (see the data and methods section above). The main categories are presented in Table 8 together with the associated frequencies and a listing of where we placed each TAPG in the schema.

Table 8. Frequency of movement domains and associated TAPGs

\begin{tabular}{|c|c|c|c|c|}
\hline Domain & Description & n & $\%$ & Associated TAPGs \\
\hline Multi-issue & $\begin{array}{l}\text { Address many issues each on } \\
\text { their own }\end{array}$ & 50 & 19.0 & CCS, CRID, TWF \\
\hline Critical liberal & Substantive human rights & 41 & 16.2 & ITeM, TWN \\
\hline Alter-globalization & Oppose neo-liberal globalization & 37 & 14.1 & $\begin{array}{l}\text { Focus, IFG, PRIA, } \\
\text { TNI }\end{array}$ \\
\hline Liberal humanitarian & Formal human rights and charity & 22 & 8.4 & \\
\hline Intersectional & $\begin{array}{l}\text { Interconnectedness between } \\
\text { multiple issues }\end{array}$ & 20 & 7.6 & $\begin{array}{l}\text { Alter-Inter, People's } \\
\text { Plan }\end{array}$ \\
\hline Ecological & Environmental issues & 20 & 7.6 & \\
\hline Global solidarity & $\begin{array}{l}\text { Solidarity among nations and } \\
\text { peoples }\end{array}$ & 16 & 6.1 & $\begin{array}{l}\text { CACIM, CETRI, } \\
\text { NIGD }\end{array}$ \\
\hline Feminist & Gender justice & 12 & 4.6 & DAWN \\
\hline Anti-capitalist & Alternatives to capitalism & 6 & 2.3 & RosaLux \\
\hline Other frames ${ }^{\mathrm{a}}$ & Not elsewhere classified & 29 & 11.0 & \\
\hline Missing & No domain could be determined & 10 & 3.8 & \\
\hline Total & & 263 & 100.0 & \\
\hline
\end{tabular}

${ }^{a}$ Includes pacifist groups $(\mathrm{n}=4)$, peasant groups $(\mathrm{n}=4)$, anti-racist and anti-colonial groups $(\mathrm{n}=3)$, groups focusing on drug policy ( $n=3$ ) and groups focusing on freedom of information $(n=3)$, as well as eleven universities and one private business for which no domain was coded.

This tabulation offers a rough picture of the political composition of the segment of global civil society in which TAPGs are immediately embedded. It is in the first place interesting to note the ideological diversity of the formation. Nearly one-fifth of the 263 organizations (including three TAPGs) cast their projects within multi-issue frames: they do not focus on a single concern but on a range - without, however, providing a strong analysis of how those 
issues may be interrelated. "Critical liberal" groups, comprising $16 \%$ of the formation (including two TAPGs), emphasize substantive human rights issues without articulating a critique of relations of production. Alter-globalization - focusing on a strong critique of transnational neoliberalism and its institutions - account for another 14\% (and four TAPGs). Liberal humanitarianism, a frame that promotes international charity and falls well within hegemonic discourse, claims $8 \%$ of the network; intersectional political projects that provide an explicit analysis of the inter-relations between multiple issues, and ecological political projects that focus on impacts of humans on their environment also each represent $8 \%$ of the network. Frames that emphasize global solidarity, feminist, and anti-capitalist politics account respectively for $6 \%, 5 \%$, and $2 \%$ of the 263 INGOs (and five TAPGs in total).

The classification is admittedly imperfect; for instance, our categorization of DAWN as feminist, while accurate, ignores its deep and longstanding commitment to "interlinkage analysis," a strong form of intersectionality. And although RosaLux is the only TAPG that articulates a clear, anti-capitalist (and democratic socialist) perspective, critiques of neoliberal policies and corporate power, and advocacy of alternatives, are the stock-in-trade of all 16 TAPGs. In any case, what this analysis of the frames that predominate among TAPGs and in their immediate neighborhoods indicates is considerable diversity. The range represented among the neighbors is particularly broad, extending from the liberal mainstream to radical anti-capitalism. The question is, how are these perspectives socially organized into a global network within which the alternative policy groups are active, and how do the latter mediate relations in the former?

In the introduction, we suggested that TAPGs' contribution to transnational historical bloc formation might involve their bridging across political frames to foster a "convergence across difference." From the above categorization of TAPGs and their neighbors, we can pursue a network-based approach to grappling with this issue. The question can be put as follows: how extensively do TAPGs connect with INGOs in ways that bridge across movement domains, to connect movement actors whose self-understandings differ, into articulated ensembles of communication and practice?

Figure 5 plots in a bipartite sociogram the relationships between TAPGs and neighboring organizations, aggregating the latter according to the main political frames to which they subscribe. By aggregating TAPGs' network neighbors into meta-nodes representing predominant domains of movement politics, we are able to observe how alternative policy groups connect with the broad segments of global civil society in which they are embedded. TAPGs are represented by dots (gold indicating South-based, blue indicating North-based); aggregations of INGOs categorized within each major movement domain are represented by black squares. The configuration is arranged according to a spring embedded layout. Line thickness indicates the density of links between nodes, and the graph leaves out links with density lower than 0.1 so as to capture only the stronger relations between TAPGs and domains.

The figure indicates that TAPGs do occupy strategic positions between movement domains, and that their relations are not limited to groups associated with their own domain.

\footnotetext{
${ }^{9}$ For example, a group could have separate programs addressing environmental degradation, gender inequality, and racism, but not formulate an analysis of how women of racial minorities face double discrimination, how environmental issues could affect women and/or racial groups in specific ways (see Salleh 2009), and so on.
} 
Figure 5. TAPGs mediating between movement domains

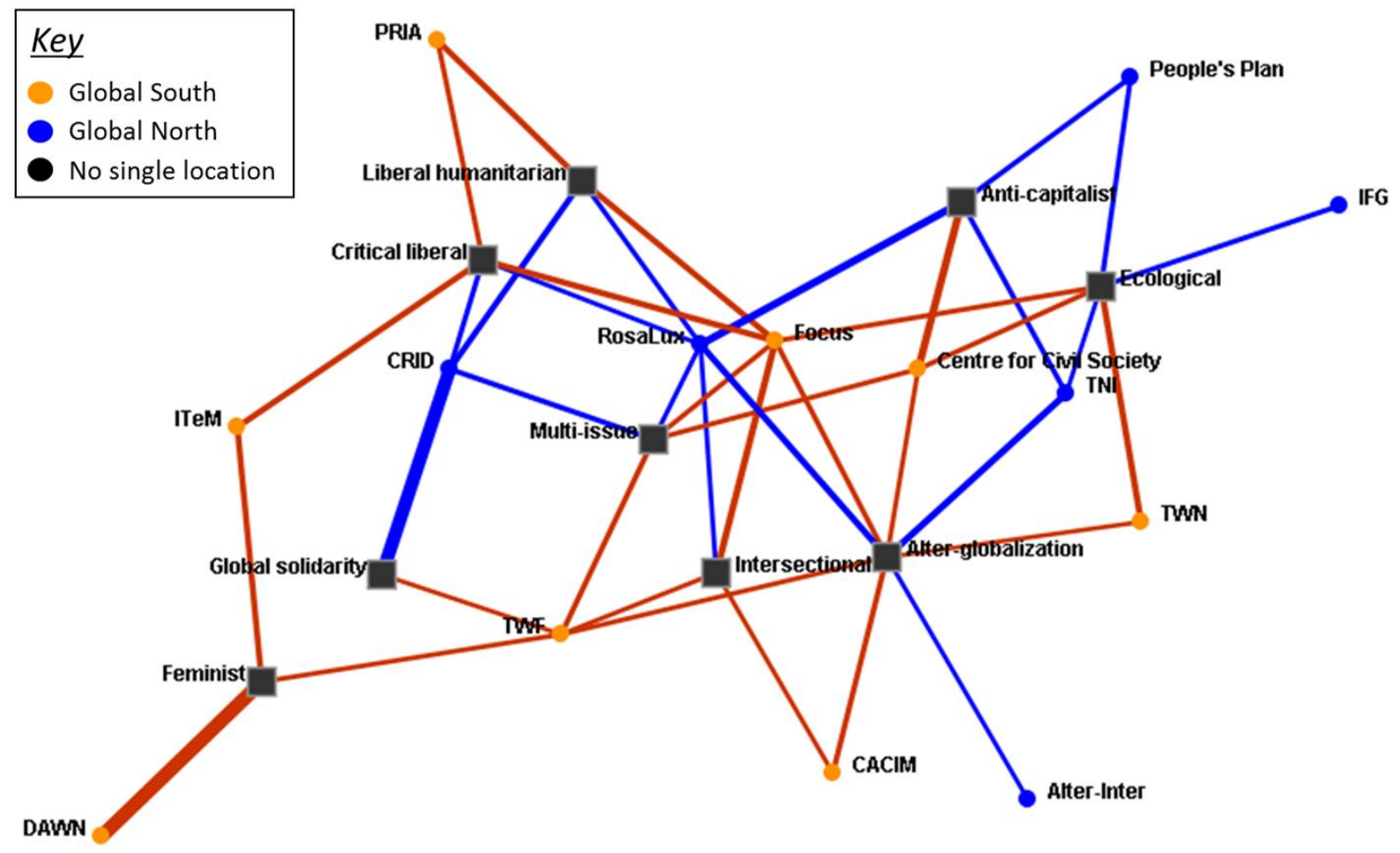

Focus and RosaLux each mediate among six different domains (including the liberalhumanitarian sector), with RosaLux showing relatively extensive ties to anti-capitalist groups. Third World Forum maintains ties to five movement domains. The Centre for Civil Society, also with extensive links to anti-capitalist INGOs, mediates among four different domains (including critical liberal groups), as does CRID, whose connections with global solidarity groups are particularly profuse. Only three TAPGs, DAWN, ${ }^{10} \mathrm{IFG}$, and Alternatives International, maintain substantial ties to just one of the major domains. ${ }^{11}$ Viewing the sociogram from the perspective of movement domains, eight TAPGs connect with the alter-globalization domain, six connect to the ecological domain, five are tied to groups with multi-issue frames, and five are tied to the critical-liberal segment. Additionally, four TAPGs link to groups whose political projects can be described as anti-capitalist, intersectional, or liberal-humanitarian. This configuration suggests that, as they produce and mobilize alternative knowledge, TAPGs mediate among a plurality of movement sectors and political projects. Their cognitive praxis positions them to speak to multiple counter-publics, with the possibility of fostering a convergence across difference. The ideological frameworks with which TAPGs engage extend from liberal-humanitarian to radical anti-capitalist.

\footnotetext{
${ }^{10}$ It is well to reiterate the specificity of DAWN's project. As noted above, the group's network is understandably feminist-focused, but DAWN's own praxis brings a strongly intersectional analysis to that network, linking gender oppression to other forms of domination.

${ }^{11}$ CETRI does not have links to any domain above the cutpoint density of 0.1 and thus does not appear in the figure.
} 
A final measure of the extent to which TAPGs mediate among groups within global civil society can be seen in the heterogeneity of each group's immediate neighborhood, as presented in Table 9. A group whose neighborhood, or social circle, is heterogeneous has direct ties to a

Table 9. Heterogeneity of TAPGs' neighborhoods

\begin{tabular}{|c|c|c|c|c|}
\hline \multirow{2}{*}{ TAPGs } & \multirow{2}{*}{ Size } & \multicolumn{3}{|c|}{ Heterogeneity } \\
\hline & & $\operatorname{Region}(n=253)^{a}$ & North-South $(n=253)^{a}$ & Domain $(n=253)^{a}$ \\
\hline Alter-Inter & 10 & 0.760 & 0.320 & 0.716 \\
\hline CACIM & 20 & 0.699 & 0.360 & 0.790 \\
\hline $\mathrm{CCS}$ & 44 & 0.780 & 0.500 & 0.851 \\
\hline CETRI & 5 & 0.480 & 0.480 & 0.720 \\
\hline CRID & 37 & 0.197 & 0.193 & 0.815 \\
\hline DAWN & 23 & 0.781 & 0.434 & 0.760 \\
\hline Focus & 46 & 0.742 & 0.478 & 0.858 \\
\hline IFG & 8 & 0.449 & 0.408 & 0.688 \\
\hline ITeM & 21 & 0.803 & 0.499 & 0.780 \\
\hline NIGD & 5 & 0.720 & 0.480 & 0.720 \\
\hline PPSG & 17 & 0.311 & 0.208 & 0.803 \\
\hline PRIA & 16 & 0.719 & 0.469 & 0.738 \\
\hline RosaLux & 38 & 0.696 & 0.498 & 0.805 \\
\hline TNI & 19 & 0.742 & 0.492 & 0.715 \\
\hline TWF & 23 & 0.767 & 0.159 & 0.785 \\
\hline TWN & 24 & 0.752 & 0.483 & 0.826 \\
\hline Mean, TAPGs & 22.3 & 0.6499 & 0.4038 & 0.7731 \\
\hline Std. Dev., TAPGs & 13.0 & 0.1851 & 0.1199 & 0.0525 \\
\hline Mean, non-TAPGs & & 0.3700 & 0.2427 & 0.4590 \\
\hline Std. Dev., non-TAPGs & & 0.3072 & 0.2170 & 0.2995 \\
\hline Mean, All orgs & & 0.3834 & 0.2529 & 0.4788 \\
\hline Std. Dev., All orgs & & 0.3086 & 0.2157 & 0.3000 \\
\hline$E t a^{2}$ & & 0.0506 & 0.0332 & 0.0652 \\
\hline
\end{tabular}

${ }^{\mathrm{a}}$ Missing values excluded

diverse array of other groups. The heterogeneity index (which varies from 0 to 1 ) shows that, overall, TAPGs have much more diversified social circles than the other organizations, across all three variables - region, North/South, and movement domain. Despite great differences in the size of their social circles (already evident above in Table 3), all TAPGs maintain social circles that take in a diverse range of movement domains. And, with the exceptions of CRID and PPSG (whose social circles are nationally-focused), TAPGs show much higher levels of diversity in bridging regional and North/South differences. 


\section{Discussion}

From several vantage points, our exploration of the embeddedness of transnational alternative policy groups suggests that they are indeed positioned to mediate across differences in global civil society, and thus to facilitate the formation of a transnational counter-hegemonic bloc.

- While not the most central organizations within their segment of GCS, most TAPGs are relatively central, and connected to such highly central actors as the Climate Justice Network, the Global Campaign Against Poverty, Friends of the Earth International, and of course the World Social Forum. As producers of alternative knowledge, TAPGs connect extensively with what Smith and Wiest (2012) call transnational social movement organizations, but they do not dominate the segment of global civil society in which they are immediately embedded. Rather, their centrality stems in part from ties to key groups that are oriented toward political process (WSF) or political action (EAN, CJN, GCAP, FoEI).

- TAPGs have a demonstrable, structurally integrative impact upon GCS, as indicated by the effects of removing their mediating ties from the network of INGOs in which they are embedded. That segment of global civil society derives considerable structural coherence and connectivity from the mediation provided by TAPGs.

- Closer examination of the role TAPGs play in integrating INGOs across space shows them to be regionally extraverted in their ties to other GCS actors. However, patterns of extraversion-introversion across the eight regions vary quite substantially, and there is a sharp difference between Northern and Southern TAPGs in their regional mediations. Northern-based TAPGs tend to be more regionally introverted, and show less of a tendency to link North/South, compared to Southern TAPGs, which are extraverted both in North/South ties and in linking across the regions of the South.

- TAPGs vary greatly in the extent to which they broker ties between other INGOs, and in the extent to which such brokerage mainly reinforces intra-regional relations or contributes to inter-regional, North-South integration. In constructing an historical bloc for alter-globalization, all three forms of regional mediation are strategically important. And given the legacy of Eurocentric capitalist development, it is not surprising that Northern-based groups mediate relations between many Northern groups, as an aspect of a Northern left that has been relatively well-resourced and, since the inception of the First International (1864), in some measure internationalist. Building solidaristic relations among civil society actors in the global North has been an important facet of recent alterglobalization activism. But if Northern-based TAPGs are strongly inclined to mediate relations between Northern organizations, TNI and RosaLux show more balanced profiles involving many Southern-based groups. For Southern-based TAPGs, all three kinds of brokerage may be seen as contributing importantly to historical bloc formation. North/South mediations help bridge that divide, as do North/North mediations. South/South mediations help solidify a Southern network within GCS, which can be taken as integral to any post-colonial global left. We find that Southern TAPGs mediate extensively between global North and South, and even between pairs of Northern INGOs, and that several of them are heavily involved in mediating South-South relations.

- As for movement domains and the framing of political projects, the segment of GCS in which TAPGs are ensconced contains a great diversity of perspectives on contemporary 
relations of domination, from mainstream to radical anti-capitalist, and TAPGs play a definite, though again uneven, role in mediating across domains. All TAPGs contain, within their social circles, heterogeneous ensembles of political frames. In this way, the relations TAPGs maintain with other organizations of global civil society "connect the dots" between movement domains that are sometimes understood as free-standing entities, as in single-issue politics - perhaps most significantly, ecological and social justice concerns.

In all these respects, transnational alternative policy groups are socially embedded to communicate with and mediate between a diverse array of collective actors, North and South. The practices that define TAPGs as distinct organizations within global civil society implicate them in these relations. To produce and mobilize critical knowledge for social change requires that these groups form such relations with change agents within global civil society, just as elite policy-planning groups, to be efficacious, need to maintain extensive networks that reach into and enable dialogue with the top tier of the transnational capitalist class and its intellectuals. The political content of the transnational blocs, however, differs starkly; alternative knowledge producers seek to transform existing social relations, while the knowledge issuing from hegemonic policy groups is intended to manage and reproduce the capitalist status quo in ways that combine efficiency with securing popular consent (Carroll 2007). If with Howarth (2010: 318) we view counter-hegemony as involving "the linking together of disparate demands to forge projects or 'discourse coalitions' that can contest a particular form of rule, practice or policy," it is evident that transnational alternative policy groups are important elements in counterhegemony, across a wide range of political domains.

Indeed, it may be partly their wide-angle view of contemporary capitalism and its maladies (as given in our selection criteria, above) that enables TAPGs to act as network integrators. Here, McPherson's (1990) distinction between specialist organizations (those with narrowly defined goals) and generalist organizations is helpful. TAPGs fall into the latter category. In organization studies, generalists have been found to play a broader role in interorganizational collective action (Barnett, Mischke, and Ocasio 2000; Shumate and Lipp 2008). The work of TAPGs, again, parallels that of the transnational policy groups that lend cohesion to the global corporate elite. In both cases, the groups produce and mobilize knowledge that is framed beyond particular and immediate interests, whether of civil-society organizations or of global corporations whose primary concern is their own profitability. But the historical blocs that TAPGs and hegemonic policy groups help organize are set against each other. In the case of TAPGs, their social ties position them to participate in the transformation of the democratic globalization network from a gelatinous and unselfconscious state (cf. Smith 2008: 226), into an historical bloc capable of collective action toward an alternative global order.

\section{Conclusion}

All this being said, there are significant gaps in the network we have explored, and thus in what may be a nascent historical bloc for alter-globalization. Entirely or largely absent from the network are organizations based in Russia and China. Europe, on the other hand, is especially central, as a site for many INGOs. We have noted a tendency among the Northern-based TAPGs to integrate a Northern network, while Southern TAPGs are heavily involved both in North- 
South and South-South relations. The heavy involvement of Southern TAPGs in the global network contrasts with findings from other studies of NGOs, which have discerned a NorthSouth divide whereby Southern NGOs tend not to form relationships beyond the local level while Northern NGOs are extensively connected internationally (Shumate and DeWitt 2008: 419). Among the TAPGs we have studied here, the Southern groups tend to be more cosmopolitan, both in their direct relations and in the relations they mediate. Again, their commitment to wide-ranging rather than single-issue analysis pushes them to connect the local and the global, and thus to mediate relations trans-locally.

Other gaps in the bloc, and limits in political framing, also merit discussion. Although in the Gramscian tradition, an historical bloc organizes the political project of a "fundamental class" and its allies, labor is rather weakly represented in the TAPG-centered network. Its main international organization, the ITUC, is tied only to the Rosa Luxemburg Foundation, and none of the political frames that inform the work of INGOs in the network directly takes up labor issues. Similarly, although we have featured "post-capitalist alternatives" in this paper's title, our analysis of political frames revealed that only $2.3 \%$ of organizations in the TAPG-centered network defined their project primarily as anti-capitalist - suggesting a reluctance of these groups to articulate a definite post-capitalist social vision. Here again, the Rosa Luxemburg Foundation is an exception, with its socialist commitment (expressing the political project of Germany's Left Party, Die Linke) and its extensive inter-continental ties spanning North and South. In general, TAPGs seem to operate pragmatically within what Unger (2009: xxi) has called the "adjacent possible":

The possible that counts is not the fanciful horizon of possibilities but the adjacent possible: what is accessible with the materials at hand, deployed in the pursuit of movement in the desired direction.

However, principled pursuit of the adjacently possible, in a way that connects across political domains, has transformative potential as a transitional program that sets in motion changes pointing to a post-capitalist future.

The limits of our method must also be acknowledged. We have presented an architectonic analysis of the region of global civil society in which transnational alternative policy groups are embedded. Although the groups are positioned in ways that mediate and integrate, the substantive content of the relations that these centers of knowledge production and mobilization maintain with other organizations has not been examined here. Although the structure of relations is consistent with the inference that TAPGs are active agents of counter-hegemony, one could also draw a different conclusion.

It could be that TAPGs (or some of them), despite their political ambitions, are caught up in a process of "NGO-ization," as astutely analyzed by Alvarez (1999). Focusing on feminist politics, she noted that trends within NGOs toward professionalization and institutionalization, together with the retreat of neoliberal states from direct social programming, gave rise in the 1990s to a situation in which neoliberal governments and IGOs have come to view NGOs "as surrogates for civil society, assuming they serve as 'intermediaries' to larger societal constituencies," while NGOs are increasingly subcontracted to advise on or deliver government programs (1999: 181). The danger in this "neoliberalization of civil society" (Goldman 2005: 270-1) is that NGOs come to serve as gatekeepers for national and global governance, acting "as brakes on more radical and exceptional ideas emanating from the developing world" (Bob 2005: 194). On this interpretation, the role NGOs, including potentially transnational alternative policy 
groups, play as "intermediaries" (Choudry 2010) may have more to do with maintaining the hegemonic bloc than with constructing a counter-hegemonic alternative. ${ }^{12}$

What limited research exists on the practices of transnational alternative policy groups suggests that their efforts center upon weaving specific and localized concerns together "around the theme of resistance to neoliberal globalization and the need for social justice" (Caouette 2007: 163). Such weaving, however, is not unproblematic. Thus, for instance, Brown's (2003) study of the Third World Network, while acknowledging its impressive scope and range of alternative knowledge production, also asked whether the group's tendency to eschew strong relations with alter-globalization actors, while cultivating ties to intergovernmental organizations, has imposed limits upon its capacity to promote transformation:

There is a puzzling lack of any sense of radicalism by which is meant here a failure to provide a sustained alternative manifesto for the replacement, rather than just the reform, of the institutions of global governance. In some respects, it could be suggested that TWN has become institutionalized into the very system of global governance that it seeks to condemn. Its continuous ride on the merry-goround of intergovernmental conferences and ministerial meetings arguably lends these conventions a further degree of legitimacy. (76)

Further research should examine how transnational alternative policy groups are embedded in networks of intergovernmental organizations (in which they might come to play a gatekeeping function) and how their funding relation to foundations, UN agencies, and the like may constrict their range of action and expression, pulling them onto the terrain of liberal humanitarianism. Beyond such structural analyses, there is a need for in-depth field work to explore just how these groups produce and mobilize alternative knowledge, and what impact their efforts have upon movement activism, intergovernmental and state policies, and (trans)national political cultures.

\footnotetext{
${ }^{12}$ In her own subsequent analysis Alvarez softens her thesis and recognizes that many NGOs do crucial movementbuilding work as producers of radical knowledge. Even if "NGO-ized' NGOs show few signs of going away in the near future," there is "no $21^{\text {st }}$ century Iron Law of NGO-ization" $(2009: 180,182)$.
} 


\section{References}

Abelson, Donald E. 1995. "From Policy Research to Political Advocacy - The Changing Role of Think Tanks in American Politics." Canadian Review of American Studies 25: 93-126.

Alvarez, Sonia E. 1999. "Advocating Feminism: The Latin American Feminist NGO 'Boom."” International Feminist Journal of Politics 1(2): 181-209.

-----. 2009. "Beyond NGO-ization? Reflections from Latin America.” Development 52(2): 17584.

Barnett, William P., Gary M. Minschke, and William Ocasio. 2000. "The Evolution of Collective Strategies among Organizations." Organization Studies 21: 325-354.

Bob, Clifford. 2005. The Marketing of Rebellion: Insurgents, Media and International Activism. New York: Cambridge University Press.

Borgatti, Steve P., Martin G. Everett, and Linton C. Freeman. 2002. Ucinet for Windows: Software for Social Network Analysis. Harvard, MA: Analytic Technologies.

Brown, Graham K. 2003. "Stemming the Tide: Third World Network and Global Governance." Pp. 73-77 in Yearbook of International Co-operation on Environment and Development 2003-2004, edited by O. S. Stokke and Ø. B. Thommessen. London: Earthscan.

Burris, Val. 2008. "The Interlock Structure of the Policy-Planning Network and the Right Turn in U.S. State Policy." Research in Political Sociology 17: 3-42.

Caouette, Dominique. 2007. "Going Transnational?: Dynamics and Challenges of Linking Local Claims to Global Advocacy Networks in Southeast Asia." Pacific Focus 22: 141-66.

Carley, Kathleen M., Juergen Pfeffer, Jeffrey Reminga, Jon Storrick, and Dave Colombus. 2012. ORA User's Guide 2012. Pittsburgh (PA): Carnegie Mellon University, School of Computer Science, Institute for Software Research. Retrieved September 14, 2012 (www.casos.cs.cmu.edu/publications/papers/CMU-ISR-12-105.pdf).

Carroll, William K. 2007. "Hegemony and Counter-Hegemony in a Global Field." Studies in Social Justice 1(1): 36-66.

------. 2010. The Making of a Transnational Capitalist Class: Corporate Power in the 21st Century. London: Zed Books.

------. 2011. "Networks of Cognitive Praxis: Transnational class formation from below." Keynote address to the Conference on Global Capitalism and Transnational Class Formation, Global Studies Centre, Prague, September 16-18.

-----. 2013. "Alternative Policy Groups and Transnational Counter-Hegemonic Struggle." In Global Economic Crisis and the Politics of Diversity, edited by Y1ldiz Atasoy. London: Palgrave MacMillan.

Carroll, William K. and Colin Carson. 2003. "The Network of Global Corporations and Elite Policy Groups: A Structure for Transnational Capitalist Class Formation?" Global Networks 3(1): 29-57.

Carroll, William K. and Jean Philippe Sapinski. 2010. "The Global Corporate Elite and the Transnational Policy-Planning Network, 1996-2006: A Structural Analysis." International Sociology 25(4): 501-538.

Choudry, Aziz. 2010. "Global Justice? Contesting NGOization: Knowledge Politics and Containment in Antiglobalization Networks." Pp. 17-34 in Learning from the Ground Up: Global Perspectives on Social Movements and Knowledge Production, edited by A. Choudry and D. Kapoor. London: Palgrave MacMillan. 
Coburn, Elaine. 2010. "Resisting Neoliberal Capitalism: Insights from Marxist Political Economy." Pp. 194-226 in Relations of Global Power: Neoliberal Order and Disorder, edited by G. Teeple and S. McBride. Toronto: University of Toronto Press.

Conway, Janet. 2004. Identity, Place, Knowledge: Social Movements Contesting Globalization. Halifax: Fernwood Publishing.

Conway, Janet and Jakeet Singh. 2009. "Is the World Social Forum a Transnational Public Sphere? Nancy Fraser, Critical Theory and the Containment of Radical Possibility." Theory Culture \& Society 26: 61-84.

Coy, Patrick, Lynne M. Woehrle, and Gregory M. Maney. 2008. “A Typology of Oppositional Knowledge: Democracy and the US Peace Movement." Sociological Research Online 13(4).

Domhoff, G. William. 2006. Who Rules America? Power, Politics, and Social Change. New York: McGraw-Hill.

Ford, Lucy H. 2003. "Challenging Global Environmental Governance: Social Movement Agency and Global Civil Society." Global Environmental Politics 3: 120-134.

Freeman, Linton C. 1978/1979. "Centrality in Social Networks: Conceptual Clarification." Social Networks 1: 215-239.

Gibson-Graham, J. K. 2006. A Post-Capitalist Politics. Minneapolis: University of Minnesota Press.

Glasius, Marlies, Mary Kaldor, and Helmut Anheier, eds. 2006. Global Civil Society 2005/6. London: Sage.

Goldman, Michael. 2005. Imperial Nature: The World Bank and Struggles for Social Justice in the Age of Globalization. New Haven, CT: Yale University Press.

Gould, Roger V. and Roberto M. Fernandez. 1989. "Structures of Mediation: A Formal Approach to Brokerage in Transaction Networks." Sociological Methodology 19: 89-126.

Gramsci, Antonio. 1971. Selections from the Prison Notebooks. London: Lawrence and Wishart.

Granovetter, Mark. 1985. "Economic Action and Social Structure: The Problem of Embeddedness." American Journal of Sociology 91(3): 481-510.

Hanneman, Robert A. and Mark Riddle. 2005. Introduction to Social Network Methods. Riverside, CA: University of California, Riverside. Retrieved September 13, 2012 (http://faculty.ucr.edu/ hanneman/nettext/Introduction_to_Social_Network_Methods.pdf)

Howart, David. 2010. "Power, Discourse, and Policy: Articulating a Hegemony Approach to Critical Policy Studies." Critical Policy Studies 3(3-4): 309-335.

Katz, Hagai. 2006. "Gramsci, Hegemony, and Global Civil Society Networks." Voluntas 17(4): 333-348.

Krackhardt, David and Robert N. Stern. 1988. "Informal Networks and Organizational Crises: An Experimental Simulation." Social Psychology Quarterly 51(2): 123-140.

Krippner, Greta R. and Anthony S. Alvarez. 2007. "Embeddedness and the Intellectual Projects of Economic Sociology." Annual Review of Sociology 33: 219-240.

Macartney, Huw. 2008. "Articulating Particularistic Interests: The Organic Organisers of Hegemony in Germany and France." British Journal of Politics \& International Relations 10(3): 429-451.

McAdam, Doug. 2003. "Beyond Structural Analysis: Toward a More Dynamic Understanding of Social Movements." Pp. 281-99 in Social Movements and Networks: Relational Approaches to Collective Action, edited by M. Diani and D. McAdam. Oxford: Oxford University Press. 
McPherson, J. Miller. 1990. "Evolution in Communities of Voluntary Organizations." in Organizational Evolution: New Directions, edited by J. V. Singh. Newbury Park, CA: Sage.

Polanyi, Karl. 1944. The Great Transformation: The Political and Economic Origins of Our Time. London: V. Gollancz.

Salleh, Ariel. 2009. "Ecological Debt: Embodied Debt." Pp. 1-42 in Eco-Sufficiency and Global Justice: Women Write Political Ecology, edited by A. Salleh. London and North Melbourne: Pluto Press and Spinifex Press.

Shumate, Michelle and Lori Dewitt. 2008. "The North/South Divide in NGO Hyperlink Networks." Journal of Computer-Mediated Communication 13: 405-428.

Shumate, Michelle and Justin Lipp. 2008. "Connective Collective Action Online: An Examination of the Hyperlink Network Structure of an NGO Issue Network." Journal of Computer-Mediated Communication 14: 178-201.

Smith, Jackie. 1997. "Characteristics of the Modern Transnational Social Movement Sector." Pp. 42-58 in Transnational Social Movements and Global Politics: Solidarity Beyond the State, edited by J. Smith, C. Chatfield, and R. Pagnucco. Syracuse, NY: Syracuse University Press.

-----. 2008. Social Movements for Global Democracy. Baltimore: Johns Hopkins University Press.

Smith, Jackie and Dawn Wiest. 2012. Social Movements in the World-System. New York: Russell Sage Foundation.

Snow, David A. and Robert D. Benford. 1992. "Master Frames and Cycles of Protest." Pp. 133155 in Frontiers in Social Movement Theory, edited by A. D. Morris and C. M. Mueller. New Haven, CT: Yale University Press.

Somers, Margaret R. and Fred Block. 2005. "From Poverty to Perversity: Ideas, Markets, and Institutions over 200 Years of Welfare Debate." American Sociological Review 70(2): 160-287.

Stephen, Matthew D. 2009. "Alter-Globalism as Counter-Hegemony: Evaluating the 'Postmodern Prince.'” Globalizations 6(4): 483-498.

Stone, Diane. 2000. "Think Tanks Transnationalization and Non-Profit Analysis and Advocacy." Global Society 14: 153-172.

Stovel, Katherine and Lynette Shaw. 2012. "Brokerage." Annual Review of Sociology 38: 13958.

Unger, Roberto Mangabeira. 2009. The Left Alternative. London: Verso.

Union of International Associations. 2012. Yearbook of International Organizations. Leiden: Brill (http://ybio.brillonline.nl).

van der Pijl, Kees. 1998. Transnational Classes and International Relations. London: Routledge. Vasi, Ion Bogdan. 2011. "Brokerage, Miscibility, and the Spread of Contention." Mobilization: An International Journal 16(1): 11-24.

von Bülow, Marisa. 2011. "Brokers in Action: Transnational Coalitions and Trade Agreements in the Americas." Mobilization: An International Journal 16(2): 165-80.

Wasserman, Stanley and Katherine Faust. 1994. Social Network Analysis: Methods and Applications. Cambridge, MA: Cambridge University Press.

Wright, Erik Olin. 2010. Envisioning Real Utopias. London: Verso. 